УAK 347.122:007

DOI https://doi.org/10.32837/chc.v0i43.439

Матійко Микола ВолоАимирович,

канАиАат юриАичних наук,

Аоцент кафеАри цивільного права

Національного університету "ОАеська юрилична академія"

ORCID ID: 0000-0003-4588-2636

\title{
ОКРЕМІ АСПЕКТИ ДИФЕРЕНЦІАЦІЇ ФУНКЦІЙ ПРИВАТНОПРАВОВОГО РЕГУЛЮВАННЯ ЗАПОБІГАННЯ ВИНИКНЕННЮ I ПОШИРЕННЮ ІНФЕКЦІЙНИХ ХВОРОБ ЛЮДИНИ, ЛОКАЛІЗАЦІї Й ЛІКВІДАЦІЇ ЇХ СПАЛАХІВ ТА ЕПІДЕМІЙ
}

Постановка проблеми. Загальні тенденції суспільного життя можуть впливати на роль окремих напрямів впливу приватноправових інститутів та їхнє соціальне призначення у певних сферах. Тенденції до персоналізації, глобалізації, інформатизації та фрагментації суспільного життя піАвищують роль як окремих специфічних функцій приватноправових інститутів, так і окремих загальноправових функцій права, що проявляють себе і на рівні зазначених інститутів.

Не $€$ винятком і вплив на функції зазначених інститутів поширення коронавірусної хвороби (COVID-19).

Багато правознавців Аиференційовано піАходять АО вивчення функцій правових явищ: виокремлюють функції права, функції правового регулювання, функції законодавства, функції правозастосування, функції правового виховання, функції санкцій, функції Аиспозицій, функції правового поряаку [1, с. 25-33; 2; 3, с. 48; 4, с. 21-27].

При цьому в юридичній мітературі висловлені Аумки про тотожність функцій права та правового регулювання. Так, В.Г. Смирнов стверАжує, що поняття "функції права" загалом виражає соціальне призначення правового регулювання, тому що в ньому проявляються в сукупності преАмет, завдання та метод регулювання [5, с. 7]. Натомість В.П. Реутов, навпаки, на приклаАі виховної та пізнавальної функцій права і правового регулювання прагне обгрунтувати необхінність їх розрізнення [4, с. 23]. В.М. Горшеньов піА функціями правового регулювання розуміє функції права у вузькому значенні, такі як владно-правовий регулятивний вплив (функції права у широкому значенні розкривають узагальнену характеристику правового впливу на суспільні відносини, коли регулювання $€$ лише одним із питань вираження службової ролі права) [6, с. 35-37].

Можна погодитися 3 думкою С.С. Алексєєва про те, що правовим регулюванням $€$ зАійснення функцій права. АосліАник вважає, що право, котре характеризується як система загальнообов'язкових норм, які охороняються державою, виражають державну волю всього народу, вказує й на всі спеціальні засоби юридичного впливу, передбачені у нормах права [7, с. 114].

Взаємозв'язок категорій "функції права» і «функції правового регулювання" не Аозволяє конструювати останню правову категорію як самостійну. Тут спостерігається гносеологічний збіг функцій права і функцій правового регулювання. Крім того, функції права та функції правового регулювання повинні збігатися за підсумком регулювання.

ОАнак вищезазначене не означає, що функції права повинні ототожнюватися з функціями засобів регулювання, передбачених у нормах права. Засоби регулювання, незважаючи на те, що вони віАповіАають певній функції права, все ж таки віАрізняються своїм функціонально-специфічним призначенням. Зокрема, хоч сукупність певних прав та обов'язків і віАповідає тій або іншій функції права, проте їхня безпосереАня функція полягає у наданні особі можливості певної поведінки, звернення за захистом тощо. 
Таким чином, спостерігається подвійна функціональна орієнтація елементів, що становлять правове регулювання: на виконання свого функціонального призначення й на відповідну функцію права.

Теоретичні розробки функціональних аспектів права, правового регулювання та інших правових явищ можуть бути застосовані й до приватноправового регулювання запобігання виникненню і поширенню інфекційних хвороб ^юАини, локалізації й ліквідації їх спалахів та епідемій.

Стан досліАження теми. АосліАженню функцій приватного права, цивільного права, приватноправового регулювання присвячено низку наукових робіт. СереА науковців, які досліджували цю проблематику, варто віАзначити С.С. Алєксєєва, В.С. Ковальського, С.Т. Максименко, М.Г. Проніну, Т.Н. Радька, А.Я. Риженкова, Є.О. Харитонова, Н.А. Чечину та інших. Проте і дотепер ця проблематика залишається не Аосить розробленою Аля вітчизняної правової Аоктрини.

Метою статті є АосліАження функцій приватноправового регулювання запобігання виникненню і поширенню інфекційних хвороб люАини, локалізації та ліквідації їх спалахів та епідемій за Аопомогою з'ясування сутності й природи явища зазначених функцій, напрямів впливу засобів цього регулювання; а також аналіз соціального призначення регулювання запобігання виникненню і поширенню інфекційних хвороб. На тлі перетину публічних і приватних інтересів в умовах пандемії COVID-19 функціональні аспекти приватноправового регулювання не можуть залишатися без змін. Загальні тенденції суспільного життя можуть впливати на роль окремих напрямів впливу приватного та цивільного права й їх соціальне призначення. Зазначене належним чином актуалізує це досліАження.

\section{ВиклаА основного матеріалу АосліАження} з повним обґрунтуванням отриманих наукових результатів. Закон України "Про захист населення віА інфекційних хвороб", визначаючи правові, організаційні та фінансові засади Аіяльності органів виконавчої влаАи, органів місцевого самоврядування, підприємств, установ та організацій, спрямованої на запобігання виникненню і поширенню інфекційних хвороб ^юАини, локалізацію та ліквідацію їх спалахів та епідемій, встановлюючи права, обов'язки та віАповідальність юридичних і фізичних осіб у сфері захисту населення віА інфекційних хвороб, формує й основні напрями впливу та соціальне призначення правового регулювання запобігання виникненню і поширенню інфекційних хвороб ^юАини, зокрема напрями впливу та соціальне призначення приватноправового регулювання зазначеної сфери. Вищенаведене окреслює функціональні аспекти приватноправового регу^ювання запобігання виникненню і поширенню інфекційних хвороб люАини, мокалізації й ліквідації їх спалахів та епідемій.

У системі функцій права важливе місце посідає регулятивна функція. Призначення права - регу^ювати суспільні відносини - може втілюватися у формі Аоговорів, нормативних, правозастосовних актів, у встановленні правового статусу, правосуб'єктності, визначенні (передбаченні) юриАичних фактів, встановленні конкретного правового зв'язку між суб'єктами права, визначенні оптимального типу правового регулювання щодо конкретних суспільних віАносин тощо. Особливості цієї функції полягають насампереА у запроваАженні позитивних правил повеАінки, в організації суспільних віАносин, у коорАинації соціальних взаємозв'язків. Регулятивна функція приватноправових засобів регулювання запобігання виникненню і поширенню інфекційних хвороб мюдини, мокалізації й міквідації їх спалахів та епідемій може полягати у: 1) регулюванні лікування хворих на інфекційні хвороби; 2) оплаті профілактичних і протиепідемічних заходів та мікування хворих на інфекційні хвороби; 3) оплаті та матеріально-технічному забезпеченні робіт, пов'язаних із епідеміологічним обстеженням, ліквідацією епідемій та спалахів інфекційних хвороб, порядку відшкодування понесених на це витрат; 4) організації та проведенні профілактичних і протиепідемічних заходів (в тому числі (зокрема, але не виключно) підприємствами, установами та організаціями незалежно віА форм власності, а також громадянами); 5) проведенні профілактичних щеплень, наданні об'єктивної інформації про щеплення, піАготовці меАичних працівників, які проводять профілактичні щеплення; 6) зАійсненні контролю за якістю та застосуванням медичних імунобіологічних препаратів (у тому числі (зокрема, але не виключно) за зберіганням, транспортуванням, а також знешкодженням неприАатних Аля використання меАичних імунобіологічних препаратів); 7) інформуванні про випаАки поствакцинального усклаАнення, проведенні профілактичних меАичних огляАів, Заходів стосовно осіб, хворих на інфекційні хвороби, контактних осіб та бактеріоносіїв, віАстороненні віА роботи осіб, які є бактеріоносіями; 8) здійсненні санітарно-епідеміологічного нагляду, запровадженні 
необхідних піА час дії карантину профілактичних, протиепідемічних та інших заходів, встановленні термінів їх проведення, тимчасових обмежень прав фізичних та юридичних осіб (та Аодаткових обов'язків, що покладаються на них), підстав та порялку обов'язкової самоізоляції; 9) залученні піАприємств, установ, організацій незалежно віА форм власності до виконання заходів із ^окалізації та ліквідації епідемії чи спалаху інфекційної хвороби; 10) залученні Аля тимчасового використання транспортних засобів, будівель, споруд, обладнання, іншого майна підприємств, установ, організацій незалежно віА форм власності, необхідного Аля зАійснення профілактичних і протиепідемічних заходів, із подальшим повним відшкоАуванням у встановленому законом порядку його вартості або витрат, пов'язаних з його використанням; 11) запровадженні більш жорстких, ніж встановлені нормативно-правовими актами, вимог щодо якості, умов виробництва, виготовлення та реалізації продуктів харчування, режиму обробки та якості питної води, поширенні інформації про випадки захворювання на період карантину; 12) встановленні основних принципів профілактики інфекційних хвороб (сереА яких (зокрема, але не виключно) Аотримання підприємствами, установами, організаціями незалежно віА форм власності та громадянами санітарно-гігієнічних і санітарно-протиепідемічних прави^ та норм піА час здійснення будь-яких видів Аіяльності), прав та обов'язків громадян й їх об'єАнань у сфері захисту населення віА інфекційних хвороб, прав та обов'язків підприємств, установ й організацій у сфері захисту населення віА інфекційних хвороб, прав та обов'язків осіб, які хворіють на інфекційні хвороби чи є бактеріоносіями, тощо.

НеобхіАність в охороні суспільних віАносин існувала завжАи і буде існувати Аоти, Аоки існуватиме суспільство. Цей прояв правового впливу і становить охоронну функцію. Охоронна функція права - це зумовлений соціальним призначенням напрям правового впливу, спрямований на охорону загальнозначущих, найбільш важливих економічних, політичних віАносин, усунення явищ, проти яких виступає суспільство. Охоронна функція приватноправового регулювання запобігання виникненню і поширенню інфекційних хвороб ^юдини, ^окалізації й міквідації їх спалахів та епіАемій полягає у захисті віА порушень прав суб'єктів зазначеної сфери та встановленні відповіАальності юридичних і фізичних осіб та інших суб'єктів приватноправових відносин у сфері захисту населення віА інфекційних хвороб за: 1) недотримання підприємствами, установами, організаціями незалежно віА форм власності та громадянами санітарно-гігієнічних і санітарно-протиепідемічних правил та норм піА час зАійснення будь-яких видів Аіяльності; 2) невиконання обов'язків із організації та проведення профілактичних і протиепідемічних заходів, профілактичних щеплень; 3) неАотримання вимог Ао меАичних імунобіологічних препаратів, контролю за їх якістю та застосуванням; 4) невиконання обов'язків зі зберігання, транспортування, а також знешкодження непридатних Аля використання меАичних імунобіологічних препаратів; 5) порушення прав піАприємств, установ і організацій та невиконання ними обов'язків у сфері захисту населення віА інфекційних хвороб; 6) порушення прав осіб, які хворіють на інфекційні хвороби чи є бактеріоносіями, та невиконання ними своїх обов'язків тощо.

Інформаційна функція права дає змогу ознайомитися 3 засобами права у задоволенні прав і правомірних інтересів осіб, можливостями найкращим чином задовольнити свої потреби, гарантіями суб'єктивних прав, способами їх захисту, можливостями мінімізувати витрати. Інформаційна функція приватноправового регулювання запобігання виникненню і поширенню інфекційних хвороб люАини, локалізації й ліквідації їх спалахів та епідемій полягає в ознайомленні суб'єктів із: 1) правами та обов'язками в зазначеній сфері; 2) принципами профілактики інфекційних хвороб (в тому числі (зокрема, але не виключно) Аотриманням підприємствами, установами, організаціями незалежно віА форм власності та громадянами санітарно-гігієнічних і санітарно-протиепідемічних правил та норм піА час зАійснення буАь-яких виАів Аіяльності; комплексністю провеАення профілактичних, протиепідемічних, соціальних й освітніх заходів; принципи в цьому аспекті проявляють чималий інформаційний потенціал, маючи велике значення Аля інформаційної функції [8, с. 16]); 3) загальними тенденціями приватноправового регулювання зазначеної сфери; 4) інформацією про щеплення, наслідки відмови віА них та можливі поствакцинальні усклаАнення; 5) легальними визначеннями явищ цієї сфери (інфекційні хвороби, небезпечні інфекційні хвороби, особливо небезпечні інфекційні хвороби, Ажерело збудника інфекційної хвороби, дезінфекційні заходи, епідемія, епідемічна ситуація, благополучна епідемічна ситуація, нестійка епідемічна ситуація, неблагополучна епідемічна ситуація, інкубаційний період, самоізоляція, обсерватор, календар профілактичних щеплень, контактні 
особи, карантин, медичні імунобіологічні препарати, носій збудника інфекційної хвороби, обмежувальні протиепідемічні заходи, осередок інфекційної хвороби, санітарно-протиепідемічні правила і норми, протиепідемічні заходи, профілактичні щеплення, поствакцинальні усклаАнення, спалах інфекційної хвороби, санітарна охорона території України, фактори передачі збуАників інфекційних хвороб, обсервація тощо).

Ефективність інформаційної функції правових Аефініцій багато в чому залежить віА повноти визначення окремих понять основних положень права. Ст. 1 Закону України «Про захист населення віА інфекційних хвороб" надає визначення наведених вище понять. Включення Ао законів та піАзаконних нормативно-правових актів зазначеної сфери розділів, присвячених фіксації спеціальних положень щодо регульованої актом законодавства специфічної сфери віАносин, визначенню понять цієї сфери, сприятиме посименню інформаційної функції права. Отже, застосування такого піАходу $є$ виправданим. Він часто застосовується у правотворчій Аіяльності, але в окремих сферах відчувається його недостатність (зазначена недостатність, на нашу думку, віАчувається й у сфері запобігання виникненню і поширенню інфекційних хвороб людини, локалізації й ліквідації їх спалахів та епідемій). Не залишається без застосування цей піАхіА й у практиці складання цивільно-правових Аоговорів.

Багатофакторність процесу формування правосвідомості у сучасному світі зумовлена, зокрема, процесами інформатизації та фрагментації суспільного життя, піАсилює необхіАність звернення уваги на виховання у правовій сфері. При цьому Аля того, щоб механізми права Аосягли соціальних результатів, правові норми мають бути сприйняті суб'єктами віАносин та виконуватися ними. Вирішення цього завдання забезпечується, зокрема, і виховною функцією права. В цьому аспекті важливим вважається не просто знання права, а і його сприйняття. Виховна функція приватноправового регулювання запобігання виникненню і поширенню інфекційних хвороб ^юАини, ^окалізації й ліквідації їх спалахів та епіАемій полягає у вихованні поваги Ао прав суб'єктів у зазначеній сфері, правопорядку, впливу на Аумки та віАчуття люАей, Ауховну сферу 3 метою запобігання виникненню і поширенню інфекційних хвороб люАини, ^окалізації й ліквіАації їх спалахів та епідемій, Аотримання піАприємствами, установами, організаціями незалежно віА форм власності і громадянами санітарно-гігієнічних та санітарно-протиепідемічних правил і норм піА час зАійснення будь-яких виАів Аіяльності, застосування обмежувальних протиепідемічних заходів, надання взаємодопомоги суб'єктам Аля Аосягнення визначених цілей.

Уповноважувальна функція приватноправового регулювання запобігання виникненню і поширенню інфекційних хвороб люАини, ^окалізації й ліквіАації їх спалахів та епідемій полягає у: 1) створенні передумов Аля саморегулювання; 2) встановленні принципів внутрішнього регулювання за Аопомогою угоди сторін у сфері запобігання виникненню і поширенню інфекційних хвороб; 3) можливості визначення правил повеАінки піА час проведення профілактичних і протиепідемічних заходів; 4) запровадженні більш жорстких, ніж встановлені нормативно-правовими актами, вимог Ао якості, умов виробництва, виготовлення та реалізації продуктів харчування, режиму обробки та якості питної води тощо.

Компенсаційна функція права - це дуже важмивий напрям Аії права. У ньому міститься Аосить істотна особливість права - як інструменту віАновлення справедливості. Компенсаційна функція приватноправового регулювання запобігання виникненню і поширенню інфекційних хвороб ^юАини, ^окалізації й міквідації їх спалахів та епідемій полягає у забезпеченні можливості віАновлення порушеного права та інтересу на еквівалентній основі піА час проведення профілактичних і протиепідемічних заходів, інших заходів, спрямованих на запобігання виникненню і поширенню інфекційних хвороб мюдини, локалізації й ліквідації їх спалахів та епідемій.

Отже, можна зробити припущення, що оскільки приватне право як наднаціональне утворення без умови опосередкування правом цивільним та міжнародним приватним правом також виконує певні функції (цивілізаційну, основоутворювальну, інтеграційну, ціннісну, системоутворювальну), то зазначені функції теж певною мірою можуть бути властиві й окремим приватноправовим інститутам, зокрема приватноправовому регулюванню запобігання виникненню і поширенню інфекційних хвороб людини, ^окалізації й ліквіАації ї спамахів та епідемій.

Висновки З АосліАження та перспективи подальших розвіАоК у цьому напрямі. ПіАсумовуючи вищевикладене, з огляду на зазначені функціональні аспекти приватноправового регумювання запобігання виникненню і поширенню інфекційних хвороб люАини, локалізації й ліквіАації їх спалахів та епідемій, надану характеристику 
віАповіАних функцій, можна констатувати певний рівень концептизації зазначеної сфери регулювання в аспекті розуміння, згіАно з яким "концепт $€$ феноменом, що забезпечує пізнання ^юдиною світу, себе та свого місця у світі... Термінопоняття "концепт" $€$ полісемантичним і може застосовуватися у багатьох галузях знань... Якщо в галузі філософії, мінгвістики тощо "концепт" $€$ самостійним предметом досліАження, то у більшості галузевих наук він може використовуватися в якості методологічного прийому. Зокрема, ефективним видається застосування такого підходу (мабуть, все ж таки "концептного", ніж "концептуального") у галузі права... ПіА час АосліАжень у сфері права необхінно розрізняти базові концепти (право, справеАливість, приватне право, права ^юАини, суб'єкт права, власність, Аоговір тощо) і "правові концепти" ("позитивний" закон, правовий інститут, правова норма, судовий захист, позов, преАставництво тощо)" [9, с. 31]. Зазначене може бути враховане в разі визначення бази подальших Аосліджень цієї сфери.

\section{NITEPATYPA:}

1. Алексеев С.С. Функции применения права. Правоведение. 1972. № 2. С. 25-33.

2. Быков А.Г. Роль гражданско-правовых санкций в осуществлении хозяйственного расчета : автореф. дисс. ... канд. юрид. наук : 12.00 .03 . Москва, 1967. $16 \mathrm{c}$.

3. Матузов Н.И. Личность. Права. Демократия. Теоретические проблемы субъективного права. Саратов : Издательство Саратовского университета, 1972. 292 с.

4. Реутов В.П. О разграничении функций права и правового регулирования. Правоведение. 1974. № 5. С. 21-27.

5. Смирнов В.Г. Функции советского уголовного права. Ленинград : Издательство ЛГУ, 1965. 187 с.

6. Горшенев В.М. Способы и организационные формы правового регулирования в социалистическом обществе. Москва : Юридическая литература, 1972. 256 с.

7. Алексеев С.С. Механизм правового регулирования в социалистическом обществе. Москва : Юридическая литература, 1966. C. 114

8. Матійко М.В. Інформаційна функція цивільного права : автореф. дис. ... канд. юрид. наук : 12.00.03. Одеса, 2009.20 с.

9. Харитонов С.О., Харитонова О.І. Приватне право як концепт. Том 1. Витоки. Одеса : Фенікс, 2018. 556 с.

\section{Матійко Микола ВолоАимирович \\ ОКРЕМІ АСПЕКТИ АИФЕРЕНЦІАЦІЇ ФУНКЦІЙ ПРИВАТНОПРАВОВОГО РЕГУАЮВАННЯ ЗАПОБІГАННЯ ВИНИКНЕННЮ І ПОШИРЕННЮ ІНФЕКЦІЙНИХ ХВОРОБ АЮАИНИ, АОКААІЗАЦІЇ Й АІКВІААЦІЇ ЇХ СПАЛАХІВ TA EПIАЕМІЙ}

Стаття присвячена АосліАженню функцій приватноправового регулювання запобігання виникненню і поширенню інфекційних хвороб мюдини, ^окалізації й ліквідації їх спалахів та епідемій.

За Аопомогою аналізу практики Аії норм приватного та цивільного права АосліАжено напрями впливу засобів регулювання запобігання виникненню і поширенню інфекційних хвороб люАини. Розглянуто погляАи вчених щодо напрямів впливу приватноправового регулювання на суспільні відносини, його ролі та соціального значення. Охарактеризовано прояви функціоналізму в сфері приватноправового регулювання запобігання виникненню і поширенню інфекційних хвороб мюдини.

Проаналізовано думки вчених з приводу диференціації функцій права, функцій приватного права, функцій цивільного права, функцій приватноправового регулювання запобігання виникненню і поширенню інфекційних хвороб мюдини, мокалізації й ліквідації їх спалахів та епідемій.

Визначена можливість застосування теоретичних розробок щодо поняття та структури функцій права і функцій галузей до приватноправового регулювання запобігання виникненню і поширенню інфекційних хвороб людини, локалізації й ліквідації їх спалахів та епідемій.

Підкреслено, що взаємозв’язок категорій “функції права» і “функції правового регулювання" не Аозволяє конструювати останню правову категорію як самостійну. Водночас зроблено припущення, що функції права та функції правового регулювання повинні збігатися за результатом регулювання.

Виокремлено та охарактеризовано регулятивну, охоронну, інформаційну, виховну, уповноважувальну функції приватноправового регулювання запобігання виникненню і поширенню інфекційних хвороб ^юАини, локалізації й ліквідації їх спалахів та епідемій. Також зроблене припущення, що оскільки приватне право як наднаціональне утворення без умови опосередкування правом цивільним та міжнародним приватним правом також виконує певні функції (цивілізаційну, основоутворювальну, інтеграційну, ціннісну, системоутворювальну), то зазначені функції теж певною мірою можуть бути властиві й окремим приватноправовим інститутам, зокрема приватноправовому регулюванню запобігання виникненню і поширенню інфекційних хвороб людини, локалізації й ліквіАації їх спалахів та епідемій.

Сформульовано пропозиції щодо подальшого розвитку Аосліджень функцій цивільного права, функцій приватного права, функцій приватноправового регулювання запобігання виникненню і поширенню інфекційних хвороб люАини.

Ключові слова: цивільне право, приватне право, функції цивільного права, функції приватного права, функції права, функції приватноправового регулювання, функції правового регулювання. 


\section{Matiiko Mykola \\ SOME ASPECTS OF DIFFERENTIATION OF FUNCTIONS OF PRIVATE-LAW REGULATION OF PREVENTION OF OCCURRENCE AND SPREAD OF INFECTIOUS HUMAN DISEASES, LOCALIZATION AND ELIMINATION OF THEIR OUTBREAKS AND EPIDEMICS}

The article is devoted to the study of the functions of private law regulation of prevention of the emergence and spread of infectious human diseases, localization and elimination of their outbreaks and epidemics.

By analyzing the practice of private and civil law, the directions of influence of regulatory means to prevent the emergence and spread of infectious human diseases have been studied. The views of scholars on the areas of influence of private law regulation on public relations, its role and social significance are considered. Manifestations of functionalism in the field of private-law regulation of prevention of occurrence and spread of infectious human diseases are characterized.

The views of scientists on the differentiation of legal functions, private law functions, civil law functions, functions of private law regulation of prevention and spread of infectious human diseases, localization and elimination of their outbreaks and epidemics are considered.

The possibility of application of theoretical developments concerning the concept and structure of functions of law and functions of branches to private-legal regulation of prevention of emergence and distribution of infectious diseases of the person, localization and liquidation of their outbreaks and epidemics is defined.

It is emphasized that the relationship between the categories of "functions of law" and "functions of legal regulation" is such that does not allow to construct the last legal category as an independent one. In addition, it is assumed that the functions of law and the functions of legal regulation should coincide with the result of regulation.

The regulatory, protective, informational, educational, authorizing functions of private-legal regulation of prevention of the occurrence and spread of human infectious diseases, localization and elimination of their outbreaks and epidemics are singled out and characterized. Along with the above, it is suggested that since private law as a supranational entity without the mediation of civil and international private law also performs certain functions (civilizational, fundamental, integration, value, system-forming), these functions may also to some extent be separate legal institutions, including private law regulation of prevention of the emergence and spread of infectious human diseases, localization and elimination of their outbreaks and epidemics.

Proposals for further development of research on the functions of civil law, the functions of private law, the functions of private law regulation to prevent the emergence and spread of infectious human diseases.

Key words: civil law, private law, functions of civil law, functions of private law, functions of law, functions of private law regulation, functions of legal regulation. 